ISSN: 2379-1047

Volume 6, Issue 1, 13 Pages

\title{
GREEN MARKETING: CONSUMER PERCEPTION AND KNOWLEDGE LEVEL TOWARDS PURCHASING ECO FRIENDLY PRODUCTS
}

\author{
Dr. Rambabu Lavuri ${ }^{1}$; Prof. D. Sreeramulu ${ }^{2}$ \\ ${ }^{1}$ ICSSR-Post Doctoral Fellow, Dept. of Business Management, Osmania University. \\ Email: rambabu.lavuri@gmail.com. \\ ${ }^{2}$ Dean Faculty of Management, Osmania University, Hyderabad, Telengana, India. \\ Email: profsreeramulu@gmail.com
}

\begin{abstract}
At present scenario, an environmental aspect has turned into a key issue. The green market concept has turn into the trendy expression in most recent decade because of sensational increment in environmental consciousness around the world. Purpose of the investigation is to find out the environmental consciousness and studying respondent's perception and knowledge level towards purchasing eco friendly green products. The research data were composed through survey and interview methods by the structure questionnaire from the 429 respondents from the areas of three districts of Telanagna state in India. The results revealed that respondents have positive perception with purchasing green eco friendly products and they show more environmental consciousness by the purchasing of eco-friendly products. Finally, the study concluded that the consumers are familiar about the environmental aspects and also their knowledge is high regarding green products. To increase the sales volume of ecological sustainable items, marketers need to adopt a better marketing mix for their eco-friendly items in order to change respondent's negative perception and develop eco-awareness towards green products. Similarly, government should take responsibility towards creating better awareness about environmental consciousness and eco friendly products by purchasing green products.
\end{abstract}

Keywords: Green market, eco-friendly products, intention, knowledge level, environmental consciousness.

\section{INTRODUCTION}

Biological situation and environmental security are the genuine threats that are being faced by society from the past few decades. Business enterprises and human life had a lot of impact because of the ecological issues. Green promoting paved a way in finding the reason behind ecological issues such as global warming, loss of bio-diversity, ozone exhaustion, contamination and deforestation. Recent survey results states that $88 \%$ of Americans believe that we have to take care of environment, but still $22 \%$ believe that it is the government which has to take care. From a report given in 2014, it is clear that $55 \%$ of buyers across 60 nations are interested in using the products from the organizations which are conscious about ecology even though the price of the product is higher. Indian outline expresses that $85 \%$ of the purchasers think about how green things are helpful for nature and $63 \%$ of the Indian buyers think about the green things. American Marketing Association (AMA) portray Green Marketing as "The progression of the things that are earth secure; Green exhibiting incorporates making and propelling the things and organizations that lands at the customer wants the extent that quality, cost and accessibility of the things. Progressively over they should not hurt the earth by any means (Polonsky, 1994, Mishra \& sharma, 2010 and Rakshita, 2011). To the extent 
enormous business, Green issues and Environmental Issues are for the most stage used to delineate these that endeavor to confirm or displace the qualities of the situation with the assistance of organizing criticalness and additional benefits and reducing or discarding the use of risky bosses, sullying and squandering. It is moreover insinuated as an article that is basically pertinent to the world. Awareness among the consumers towards the ecological issues and green items is improving at a greater rate (R.Mahesh \& P.Gomathi 2016). Green promoting is the marketing of the items that are assumed to combine greater extent of environmental activities such as modification to manufacturing process, items and packaging to make them sustainable, as well as creating a new way of publicizing (Faizan Zafar Sheikh, et al., 2014). In current era, ecological issues such as global warming, exhaustion of natural resources are affecting the decisions of consumers in purchasing a product directly or indirectly. The enthusiasm in humans and the desire to get the maximum with least effort resulted in destroying the fundamental supporting frameworks of life; i.e. air, water and land (Smitha 2009); the repost of world health organization stated that, Every year in India 5,27,700 deaths are due to contamination of air and $21 \%$ of the transmittable diseases are getting spread because of Water pollution (Mannarswamy, 2011); In addition, Indians are least aware of the environmental issues among the 14 nationalities surveyed (National Geography, 2008). Climate has become a standard issue and buyers are getting progressively increasingly cognizant about their penchants and their effect on the earth (Krause, 1993). A research study concludes that $69 \%$ of the public accepts that their daily life is getting affected because of the contamination and environmental issues(Schlegemilch, 1996), which confirms the proposal that buyers are progressively picking or evading items depending on their climate effect (Ottman, 1992; McDougals, 1993, Coddington, 1993; Davis, 1993 and Grove et al., 1996). Along these lines, the impact on home grown issues is all the more truly conspicuous for each body right now and happens needing securing something in one structure or the other.

\section{RECENT RESEARCH REVIEWS}

\section{Media exposure}

Most researchers presumed that the media took on an amazing activity in the extensive dispersal of the environmental concern (Morrison and Lowe, 1984; Lowe and Rudig, 1987, Mitchell, 1990). In this manner, Raymond and Mazis (1997) battled for advertisers to utilize a media mix to give ideal conditions to an arranged purchaser interest gathering. For instance, TV ads might be utilized for showcasing the items, print commercials might be utilized to impart data that is progressively itemized and to build up a brand picture, and item bundling might be utilized to pull in shoppers at the purpose of offer. Such media uses are typically combined into a single coordinated communication campaign. Schultz and Lauterborul (1993) portrayed media presentation as any open entrance for a reader, watcher, or crowd to see or hear a promotional message in a particular media vehicle. Presentation of media is a major driver of progress scattering and has a major impact on pioneers (Bass, 1969). Media introduction's most generally speaking effect on dispersing is that it spreads data of moves up to a huge assembling rapidly (Rogers 2003). Green and Peloza (2014) reviewed on effect of propelling offer type on earth neighbourly utilization and the evaluation translated that when respondents experience raised open commitment, other-advantage offers are interminably persuasive; self-advantage demands work better in private settings. Rambabu L and Sreeramulu D (2019) study concluded that media exposure has a great impact on the consumer intention and knowledge towards green purchasing. Iman Khalid and Zainuddin (2011) examined expects to distinguish the impact of media presentation, on buy aim of without lead electronic items (green gadgets) among addresses, from USM designing grounds. The study found that media exposure had a significant positive influence on lectures purchase intention. Thus expanding the portion of media will improve purchaser awareness towards environmental issues, and subsequently, effect hopeful frames of mind as media assume a significant job in impacting the mentality of customers and their dedication perspectives in natural exercises and practices. In the view of previous research, media exposure had significant impact on the green consumers towards awareness and purchasing behaviour with concerned ecological issues. 


\section{Perception and knowledge level}

According to Abdullah Osman et al. (2015) study found that there is significant connection between manager's intention on green concepts and the practice of green programs or Peninsular Malaysia fabricates practices at a relationship for green individual care things. Consumers have positive attitude regarding green marketing and green items by the great awareness of the ecological friendly items; price is the attribute that impacts on consumers green purchasing. So efforts should be made to reduce the cost of eco-friendly items (Sujith T S, 2017). Sanjeev et al. (2012); Rambabu L and Sreeramulu D (2019) studies explored that the consumers have positive concern towards environment and have high intentions to purchase green items, and analysis concluded that purchaser's shows ecological concern through purchasing eco-green items and they were even ready to pay high price to ecological friendly green items. The information on natural issues will choose individuals' conduct towards the earth. Respondents ' buying conduct is emphatically influenced by recognition and attitude (Roberts, 1996). The more the individual thinks about the regular concerns; the more prominent the conduct towards the identical could be made. Inspirational demeanours are created by definite information on ecological issues (Arcury, 1990). Ecological intention is related with the disposition and conduct of the client regarding the earth (Laroche et al., 2001). Exact data on natural issues can make individuals all the more ecologically cognizant (Schahn and Holzer, 1990). Buyers who are constantly aware of nature choose gradually green choices (Birgelen et al., 2009). The certain biological lead of an individual does not make his / her commitment or commitment to nature straightforwardly certain. The individual connection is fundamental, and the idea of data management inspiration is based on one's level of thinking (Petty and Cacioppo, 1990). In context on these disclosures it will when all is said in done be typical that the buyers who have learning and consider the biological issues will without a doubt go for green buys.

\section{Environmental concern}

A green shopper can be recognized to be the person who maintains a strategic distance from any item which may mischief or cause harm to any living life form, cause weakening of the earth during procedure of assembling or during procedure of use, and expend a lot of non-sustainable power source (Elkington, 1994). There have been various components which are instrumental in spurring green shoppers to buy green items. Broad look into throughout the years recognizes; expanded level of data accessibility on natural sustenance, green publicizing by enterprise, expanded worry for condition, and increment in prominence of green items by social and ecological foundations (Ottman, 2008). To build up great intention towards green products, especially on the part of green items, association's exertion to lengthen customer consciousness of the inexperienced things and its natural traits in the longing for engaging in buy conduct (Prakash, 2002). Be that as it may, the veritable thought of the association between ecological consciousness and ecological behaviour is still to be developed. Past investigate by Bonni and Oppenheim (2008); Maheswari and Malhorta (2011); Tolliver-Nigro (2009) and Rambabu L and Sreeramulu D (2019) have discovered that ecological consciousness has little impact on respondents conduct. Mindfulness about points of interest of a green thing's use on the earth may influence whether thing is purchased and devour (Murthy, 2010). Finisterra do Paço and Reis (2012) investigated that Elements influencing scepticism in opposition to green advancing Environmental problem has an impact on mistrust of green cases in publishing correspondence, with even greater biologically suspicious buyers turning into scientifically suspicious of inexperienced instances on applications or advertisements; no sexual influence on this heat.

\section{HYPOTHESES FRAMEWORK}

The main fundamental destinations of the flow study of research.

- To analyse consumers demographics for inclined to purchase green products;

- To study client Intention and knowledge level regarding Green purchasing; 
- To understand the extent of concerns for environmental protection by the consumers in using green items;

A research hypothesis is framed as shown in Figure 1. The figure shows the relationships between the independent variables (media Exposure, perception and knowledge levels and Environmental concern factors), and dependent items (purchasing eco friendly products). In accordance with the research framework and the priori associations developed by studies, the following research hypotheses are developed and to be tested in current study.

- Hypothesis 1: Media exposures have positive impact on consumer perception \& knowledge level towards the purchasing eco friendly products.

- Hypothesis 2: Environmental concern has a positive association with consumer perception \& knowledge level towards the purchasing eco friendly products.

- Hypothesis 3: Consumers perception \& knowledge level have positive influence on the purchasing eco friendly products.

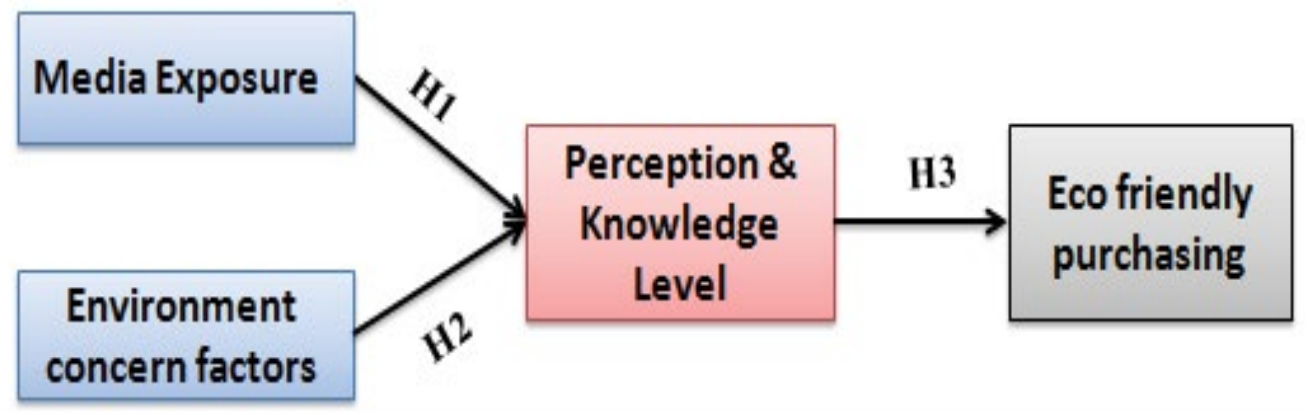

Figure 1 Hypothetical conceptual frame work

\section{MATERIALS AND METHODS}

Research is a systematic enquiry approach, it explores poignant from the essential hypothesis to design of research and collection of the data (Myers, 1999). From this study, researchers have used this ways to confirm respondents deliberate towards eco-friendly green products, and also this section involve the discussion on the data working for the study.

\section{Participants and Procedure}

The present research adopts analytical research design. For this research study, the essential data was collected from three districts of Telanagna state in India; those are Secunderabad, Hyderabad and Warangal, The scope the research study is limited to three districts of Telanagna state in India.

\section{Tools and Data collections:}

Outlook on research objectives, a questionnaire for the respondents was drafted. A Structure and closed-ended questionnaire was prepared and distributed among the respondents for capturing their responses pertaining to variable of the Green products. The questionnaire was finalized after pre test. To ensure the relevance and suitability of research questionnaire, pre-test was conducted. The questionnaire was structure two parts; in the initial part has five demographic questions of respondents and the second part was made up four major factors with 25 questions. Five questions were framed to know the influence of the media exposure on respondents; ten questions were included to assess the perception \& Knowledge Levels of the respondents towards Green items; and six questions analyse the degree of concerns for environmental protection and four questions related eco friendly purchasing. Each question 
measured different perception regarding the variable of eco-green products. Hence, respondents were given rate of responses about four eco green variables on the five point Likert scale, it has ranging from 5-Strongly agree to 1-Strongly Disagree. Composed research data were evaluated by using statistical tools like analysis of variance, Pearson correlation and multiple regressions has been used by using SPSS 23 windows version. Overall, 517 questionnaire were distributed to the sample respondents under the Convenience sampling method, we were able to receive feedback $82 \%$ (429) of the respondents from the three districts of Telanagna state.

\section{Respondents Demographic statistics}

This section discloses the demographic statistics of respondents; which includes respondent's age, gender, occupation, education and income status is presented in the table 1.

Table 1 Respondents Demographic statistics

\begin{tabular}{|c|c|c|c|}
\hline \multirow{2}{*}{\multicolumn{2}{|c|}{ Respondent's demographics }} & \multicolumn{2}{|c|}{$(N=429)$} \\
\hline & & Frequency & $\%$ \\
\hline \multirow{4}{*}{ Age } & Below 25 years & 89 & 20.7 \\
\hline & $26-35$ years & 218 & 50.8 \\
\hline & $36-45$ years & 74 & 17.2 \\
\hline & 46 and Above & 48 & 11.2 \\
\hline \multirow{2}{*}{ Gender } & Male & 284 & 66.2 \\
\hline & Female & 145 & 33.8 \\
\hline \multirow{4}{*}{ Education } & Below Degree & 98 & 22.8 \\
\hline & Degree & 120 & 28.0 \\
\hline & PG & 139 & 32.4 \\
\hline & Above PG & 72 & 16.8 \\
\hline \multirow{4}{*}{ Occupation } & Govt employee & 131 & 30.5 \\
\hline & Private employee & 153 & 35.7 \\
\hline & Business & 51 & 11.9 \\
\hline & Other & 94 & 21.9 \\
\hline \multirow{4}{*}{ Monthly income (in rupees) } & Below 25,000 & 72 & 16.8 \\
\hline & $25,001-35,000$ & 187 & 43.6 \\
\hline & $35.001-45,000$ & 85 & 19.8 \\
\hline & 45,001 and Above & 85 & 19.8 \\
\hline
\end{tabular}

\section{CONSEQUENCES AND DISCUSSIONS}

\section{Reliability and Validity Measures}

To check scale reliability and validity in the current research study, researchers calculated the Cronbach's alpha coefficient for internal consistency of all variables and the cut-off score level is 0.70 ; by using SPSS packages. The analysis results were given in table 2.

Table 2 Scale Construction

\begin{tabular}{ccc}
\hline Questionnaire & Items & Alpha \\
Media Exposure & Five & 0.761 \\
Perception \& Knowledge Levels & Ten & 0.773 \\
Environmental Concern Factor & Six & 0.817 \\
Eco friendly purchasing & four & 0.790 \\
\hline
\end{tabular}


This confirms the validity and reliability of present study variables. Alpha values were calculated one after the other for each of the variables; to examine the scale validity and reliability of the destiny take a look at. The Cronbach's alpha values for Media exposure, perception \& Knowledge Levels, Environmental Concern Factor and Eco friendly purchasing are observed to be $0.761,0.773,0.817$ and 0.790 . These values illustrated that research data have good and satisfactory validity and reliability score.

Table 3 Research variables and Sources

\begin{tabular}{cll}
\hline No & \multicolumn{1}{c}{ Variables } & \multicolumn{1}{c}{ Source } \\
1 & Media Exposure & Iman Khalid A- Qader and \\
& & Yuserrie Zainuddin (2011); Rambabu L and Sreeramulu D (2019). \\
& & Sanjeev Kumar et al. (2012); \\
& Perception \& Knowledge Levels & Anbukarasi and Dheivanai (2017); \\
& & Asha and Rathiha (2017). \\
3 & Environmental Concern Factor & Asha and Rathiha (2017); Rambabu L and Sreeramulu D (2019) \\
\hline
\end{tabular}

Table 4 Descriptive Scale Statistics

\begin{tabular}{ccccc}
\hline Variables & $\mathbf{N}$ & Mean & Std. Deviation & Variance \\
Age in years & 429 & 2.58 & 1.181 & 1.394 \\
Gender & 429 & 1.31 & 0.461 & .213 \\
Education & 429 & 3.36 & 1.062 & 1.128 \\
Occupation & 429 & 2.89 & 1.163 & 1.353 \\
Income in rupees & 429 & 2.91 & 1.138 & 1.294 \\
Media Exposure & 429 & 3.8951 & .60082 & .361 \\
Perception \& Knowledge Levels & 429 & 3.9138 & .41482 & .172 \\
Environmental Concern Factor & 429 & 3.6247 & .72973 & .533 \\
Eco friendly purchasing & 429 & 3.8042 & .66977 & .449 \\
\hline Valid N (list wise) & 429 & & & \\
\hline
\end{tabular}

Table 6 reveals that the descriptive statistics of demographic profile. The major purpose to use descriptive statistics is to provide total summary of the collection of the data and also used for the measuring the central tendency and variability of the data. The disk indicate that the mean, Std. Deviation and Variance values of Demographic profiles of the respondents and green purchasing variables, mean statistics for Age, Gender, Education, Occupation and Monthly Income are found to be 2.58, 1.31,3.36, 2.89, and 2.91; standard deviations of 1.181, 0.461, 1.062, 1.163 and 1.138. As well as above table reveals that mean statistics for Media Exposure, Perception \& Knowledge Levels, Environmental Concern Factor and Eco friendly purchasing are found 3.8951, 3.9138, 3.6247 and 3.8042; Std. Deviation values are $.60082, .41482, .72973$ and .66977 ; with the variance values are $.361,0.172,0.533$ and 0.449 respectively.

Table 5 Recently Green items purchased by respondents

\begin{tabular}{rccc}
\hline S.no & Product Name & Frequency & (N=66\%; 283 out of 429) \\
& \% & 12.7 \\
\hline 1 & Recyclable Paper products & 36 & 13.4 \\
2 & Food Products & 38 & 8.5 \\
4 & Health and Beauty products & 24 & 30.8 \\
5 & Electronic Applicants & 87 & 16.2 \\
6 & Green Packaging bags & 46 & 18.4 \\
7 & IT Equipments & 52 & $\mathbf{1 0 0 \%}$ \\
\hline
\end{tabular}

Table 5 explores that respondents recent green purchasing, $66 \%$ of respondents gave the response towards statement. 
$30 \%$ of respondents were purchase electronic applicants, $18 \%$ of respondents accounted for purchasing IT equipments. $16 \%$ of them were purchased Green packaging bags. Similarly, $13 \%, 12 \%$ and $8 \%$ of the respondents were purchased green food products, recyclable paper products and health and beauty items. The study also reveals that most of the respondents having positive awareness towards green items; but this awareness level not much influence on them towards purchasing green items.

Table 6 Respondent's awareness about the green products

\begin{tabular}{cccc}
\hline S.no & Statement & Frequency & $\mathbf{( N = 4 2 9 )}$ \\
\hline 1 & Eco friendly & 157 & \% \\
2 & Bio-degradable & 57 & 36.6 \\
3 & Recyclable & 99 & 13.2 \\
4 & Energy saver & 72 & 23.1 \\
5 & Healthy for occupants & 32 & 16.8 \\
6 & Non-Toxic products & 12 & 7.5 \\
& Total & $\mathbf{4 2 9}$ & 2.8 \\
\hline
\end{tabular}

Table 6 revealed that awareness level of respondents. Six questions were asked to respondents related to eco green items. The result found that $36 \%$ of the respondents have good awareness about green items to be ecological friendly products, $23 \%$ of respondents feel that green items were recyclable products. Similarly, $16 \%$ of them were aware as green items are more energy saver. However, $13 \%$ of them were believes that green items are Bio-degradable products. Finally, $7 \%$ and $2 \%$ of respondent's responses rate indicated that green items were Healthy for occupants and Non-Toxic products.

\section{Results of Analysis of variance}

(i) Analysis on positive influence of media exposure on respondent's perception and knowledge level towards the purchasing eco friendly products.

- Hypothesis 1: Media exposures have positive impact on consumer perception \& knowledge level towards the purchasing eco friendly products.

Table 7 Anova result

\begin{tabular}{cccccc}
\hline & Sum of square & df & Mean square & F & Sig. \\
Between Groups & 64.873 & 7 & 9.268 & 11.869 & .000 \\
Within groups & 328.735 & 421 & .781 & & $(\mathrm{p}<0.05)$ \\
total & 393.608 & 428 & & & Supported \\
\hline
\end{tabular}

Table 7 reveals that media exposure and their $\mathrm{F}$ values found to be statistically positive significant; meaning there by there is exposure of media have positive influence on respondent's perception and knowledge level towards green purchasing. Media exposure $\mathrm{F}$ values in this situation are 11.869 , and the sig. value is $.000(\mathrm{p}<0.05)$. Since the $\mathrm{F}$ value is found to be significant.

(ii) Analysis on Positive concern of respondents towards environmental protection by the purchasing eco friendly products.

- Hypothesis 2: Environmental concern has a positive influence on consumer perception \& knowledge level towards the purchasing eco friendly products. 
Table 9 ANOVAs result

\begin{tabular}{cccccc}
\hline & Sum of square & Df & Mean Square & F & SIG \\
Between Groups & 449.886 & 4 & 112.471 & 215.782 & .000 \\
Within groups & 221.000 & 424 & .521 & & $(\mathrm{p}<0.05)$ \\
total & 670.886 & 428 & & Supported \\
\hline
\end{tabular}

Table 9 results revealed that there is a significant positive concern of respondents towards the purchasing eco friendly products; Significance value is supported, because its value is smaller than $\mathrm{p}$-value $(\mathrm{p}<0.05)$. The value of $\mathrm{F}$-distribution is 215.782 with 4, 424 degree of freedom. Finally, there is significant mean difference among the two groups, thus respondents have positive concern about environmental protection by the purchasing eco friendly products.

(iii) Analysis on respondent's perception and knowledge levels towards the purchasing eco friendly products.

- Hypothesis 3: Consumers perception \& knowledge level have positive influence on the purchasing eco friendly products.

Table 8 ANOVAs results

\begin{tabular}{lccccc}
\hline & Sum of Square & DF & Mean Square & F & Sig. \\
Between groups & 46.540 & 4 & 11.635 & 5.503 & .000 \\
Within Groups & 896.528 & 424 & 2.114 & & $(\mathrm{p}<0.05)$ \\
Total & 943.068 & 428 & & & Supported \\
\hline
\end{tabular}

Table 8 , it reveals that the respondents perception and knowledge levels having positive influence with green purchasing. The value of F-distribution is 5.503, with 4, 424 degree of freedom and it significance value is .000 . Since, this value is smaller than significance value $(\mathrm{P}<0.05)$. This is indicating that the mean significance difference between the respondent's perception and knowledge levels with green products purchasing. Finally, this result revealed that respondents knowledge and awareness level have good positive opinion towards green items purchasing.

\section{Results of Pearson correlation test}

Table 10 Results of Correlations between the Media exposure and consumer perception \& knowledge level

\begin{tabular}{ccc}
\hline S.no & Media exposure & Pearson Correlations (r) \\
1 & TV Ads & $.569^{*}$ \\
2 & News paper and Magazine & $.652^{* *}$ \\
3 & Outdoor Ads & $.599^{* *}$ \\
4 & Internet Ads & $-.483^{*}$ \\
5 & Friends/ Relatives & $.714^{* *}$ \\
\hline
\end{tabular}

Sig. level at $\mathrm{p}<0.05$ at 2-tailed: *Sig. level at $\mathrm{p}<0.01$ at 2-tailed: **

Table 10 discloses that Exposure variables like Friends/ Relatives as reference group $\left(\mathrm{r}=0.714^{* *}\right)$, News paper and Magazine $\left(\mathrm{r}=0.652^{* *}\right)$ are having strongly correlated with the consumer perception \& knowledge level at the $1 \%$ significance level. Whereas, Internet Ads $\left(r=-0.483^{* *}\right)$ and TV ads $\left(r=0.569^{*}\right)$ having weak association with consumer perception \& knowledge level towards eco friendly purchasing, at 5\% significance level, Internet Ads having negative correlation with the consumer perception \& knowledge level.

Table 11 Results of Correlations between Environmental Concerns and Consumer perception \& knowledge levels.

\begin{tabular}{ccc}
\hline S.No & Environmental Concern Factors & Pearson Correlations (r) \\
1 & Green products will help to build environmental sustainability & $.697^{* *}$
\end{tabular}




\begin{tabular}{lcc}
2 & Buying environmentally friendly products-eco items for earth safe & $.710^{* *}$ \\
3 & Minimising and recycling waste & $.694^{* *}$ \\
4 & Using less polluting transportation & $-.567^{*}$ \\
5 & Using eco- green items gives a sense of satisfaction & $-.627^{*}$ \\
\hline
\end{tabular}

Sig. at $\mathrm{p}<0.05$ (2-tailed): *; Sig. at $\mathrm{p}<0.01(2$-tailed): **

This section reveals that the correlation between the environmental concern factors and Consumer perception \& knowledge levels. Environmental concern variables like Buying environmentally friendly products-eco items for earth safe $\left(\mathrm{r}=0.710^{* *}\right)$, Green products will help to build environmental sustainability $\left(\mathrm{r}=0.697^{* *}\right)$ are having strong positive relationship with Consumer perception \& knowledge levels at the $1 \%$ significance level. Whereas, Using less polluting transportation $\left(\mathrm{r}=-0.567^{* *}\right)$ and Using eco-green items gives a sense of satisfaction $\left(\mathrm{r}=-0.627^{* *}\right)$ having negative and weak association with Consumer perception \& knowledge levels at the 5\% significance level.

Table 12 Results of Correlations between Consumer perception \& knowledge levels and eco friendly purchasing.

\begin{tabular}{ccc}
\hline S.No & Awareness \& knowledge levels & Pearson Correlations (r) \\
1 & Aware on Concepts of 3-R (Reduce, Reuse and Recycle) & $.661^{* *}$ \\
2 & Green items are Non-Toxic & $.625^{* *}$ \\
3 & Green items are made from natural of renewable materials & $.657^{* *}$ \\
4 & Green products having Eco friendly packaging & $.720^{* *}$ \\
5 & Green products are Healthy for occupants & $.684^{* *}$ \\
6 & Green products are Non polluting products & $.711^{* *}$ \\
7 & Green products are Environmental issues and eco-concerns products & $.690^{* *}$ \\
8 & Environmental phrases, eco-labels and symbols & $.686^{* *}$ \\
9 & Aware on Characteristics of green products & $.608^{* *}$ \\
10 & Green products are Energy Saving & $.577^{* *}$ \\
\hline
\end{tabular}

**. Sig. at $\mathrm{p}<0.01$ at 2-tailed;

Table 12, The Pearson correlation techniques were calculated in the study, Correlation results shows that is a strong and constructive correspondence among perception \& knowledge levels of respondents towards purchasing ecogreen items. Perception and knowledge levels variables like Green products having Eco friendly packaging $(\mathrm{r}=$ $\left.0.720^{* *}\right)$, Green products are Non polluting products $\left(\mathrm{r}=0.711^{* *}\right)$ and Green products are Environmental issues and eco-concerns products $\left(\mathrm{r}=.690^{* *}\right)$ at 1 significant levels, and there is a weak association between variable like Green products are Energy Saving $\left(r=.577^{* *}\right)$ and Aware on Characteristics of green products $\left(r=.608^{* *}\right)$ with purchasing Eco green products.

\section{Results of Multiple Regressions}

It is a statistical apparatus used to obtain the value estimation of a model from predictors; it clarifies the association among predictors and dependent factors; and it helpful for recognize quality impact of predictors on dependent factors. Below a table demonstrates that the development of the speculation of the hypothesis framework.

Table 13 Summary results of Multiple Regressions

\begin{tabular}{ccccccc}
\hline $\begin{array}{c}\text { Model } \\
1\end{array}$ & IV & DP & $\mathbf{R}^{\mathbf{2}}$ & $\boldsymbol{\beta}$ & $\begin{array}{c}\text { F-value } \\
24.301\end{array}$ & $\begin{array}{c}\text { Sig. } \\
.000\end{array}$ \\
\hline 2 & $\begin{array}{c}\text { Environmental concern } \\
\text { factors }\end{array}$ & Perception \& Knowledge Levels & .495 & .357 & 27.446 & .000 \\
\hline 3 & $\begin{array}{c}\text { Perception \& Knowledge } \\
\text { Levels }\end{array}$ & Purchasing Eco- friendly products & .528 & .361 & 37.638 & .000 \\
\hline
\end{tabular}

Note: IV: Independent variable; DP: Dependent Variable 
Table 13 disclose that summary results of Multiple Regressions, total three models developed to evaluate the association among the independent items and dependent items in the research study. The table revealed that, all the regression models F-values are statistically significant. The Model-1 illustrates that exposure of media on perception $\&$ knowledge Levels towards green purchasing having a positive significant impact $(\beta=0.119, \mathrm{p} \leq 0.001)$, with $27.1 \%$ of variance explained by the independent predictors. Hence, hypothesis $\mathrm{H} 1$ is strictly supported.

Mdel-2 point outs that green consumers having more environmental concern and they are showing their concern by improve respondents perception \& knowledge Levels towards the purchasing the green products $(\beta=0.357, p \leq$ 0.001 ) which explain $49.5 \%$ of variance caused by the predictors. Finally model-3, consumers having great perception and knowledge levels on purchasing eco friendly green products, and it implies that model 3 statistically significant $(\beta=0.361, \mathrm{p} \leq 0.001)$ and $52.8 \%$ of the variance caused by the predictors on dependent variable. It concluded that respondent's perception \& knowledge level have positive impact on eco friendly green purchasing.

\section{CONCLUSIONS, RESEARCH IMPLICATIONS AND LIMITATIONS}

In India, environmental issues are rising quickly. Practicing ecological awareness has turned into the new victory mantra and is being examined by people from every one of the life. As per the research finding, researchers considered four major factors with 25 questions which mostly influence the respondent's buying behaviour for the green items in three districts of Telanagna. Present research partying that respondents has ecological consciousness and concerned about environmental protection; most of respondents are buying eco-friendly items and to support ecological protection. The study extracted major key factors that respondents consider for green purchasing; those are perception \& Knowledge levels, Media exposure, Environmental protection and eco friendly green purchasing. Research illuminates regarding key indicators of respondents deliberates towards eco-green purchasing. Along these lines, it will help policy makers and managers in formulating and executing strategies to promote green purchasing. The study results concluded that consumer's had great consciousness towards environmental protection and issues. Green companies need to provide better information regarding green items through media ads. They should focus on different types of media ads for creating more awareness towards eco-friendly green items. Green progressing is a best strategy to assume and accomplish the objectives with eco-friendly activities. Hence, the government should find a way to produce the items that don't damage environment and avoid toxic chemicals; and steady moves ought to be made by govt, instructive social orders, NGOs, business organizations and society to raise awareness among the purchasers to support ecoaccommodating green buying.

Research implications: The Central message of research directed to dismember the desire for customers Green Consumerism, to look at the factors that influence customers purchase point of green stock, The results counsel that consumer from the picked space having amazing getting mode and sought after with they're having wonderful biological included, in any case they're not pay high an impetus towards green commercialization. Finally, the present examination paper exhibited that respondent's desires having a direct association towards purchase of green items. From this green promoting progressing, having wonderful position towards the long continued running by that have reasonable involvement in additional green customers. This paper reveals that buyers wish eco-pleasing new stock from the creates, all things considered, it serves to sponsors to showcase and extend care for youth and new customers towards green stock by pondering environmental and quality points of view to draw on them. This paper encourages to academician to know the supporter goal, data and awareness level and drive that are influential on the buy of green products. It encourages them to grow new unique models towards customer conduct at the reason for buying.

Limitation of study: The research geographical area is limited to five selected cities from three states of India only. Thus, the research result and conclusions have its own boundaries. The researchers used convenience approach for the knowledge assortment that makes the study consequences not promptly generalizable. Rural market was not considered in this research, there is a scope for investigating green marketing position in rural area. 


\section{Reference}

Thomas Arcury. (1990). Environmental Attitude and Environmental Knowledge. Human Organization: Winter 1990, Vol. 49, No. 4, pp. 300-304.

Bass, F. M. (1969). A New Product Growth Model for Consumer Durables. Management Science, pp. $215-227$.

Bonni, S. \& Oppenheim, J. M.,, n.d. Helping green products grow. The McKinsey Quarterly, October, Vol 2, pp. pp. 1-8.

Coddington, W. (1993). Environmental Marketing: Positive Strategies for Reaching the Green Consumer. New York,United States: McGraw-Hill Inc..

Davis, J. (1993). Strategies for Environmental Advertising. Journal of Consumer Marketing, pp. 23-25.

DeFleur, M. \& Everette Dennis, 1998. Understanding Mass Media. 6th ed. s.1.:Boston.

Dheivanai, A. (2017). An Analytical Study on Consumers Awareness Towards Green Fast Moving Consumer Goods In Coimbatore District. International Journal of Mnagement Studies, Vol-IV(Issue-4).

Elkington, J.(1994). Towards the sustainable corporation: win-win-win business strategies for sustainable development. California Management Review, Vol. 36(No.2), pp. 90-100.

Faizan Zafar Sheikh (2014). Consumer Green behaviour toward Green Products and Green Purchase Decision. International Journal of Multidisciplinarry Sciences and Engineering, Vol. 5, pp. 1-9.

Finisterra do Paco, A. M. \& Reis, R. (2012). Factors affecting skepticism toward green advertising. Journal of Advertising , pp. 147-155.

Garg, S. K. R. \& Anita Makkar. (2012). Consumer Awareness and Perception towards Green Products: A Study of Youngsters in India.. International Journal of Marketing and Business Communication, Vol.1(Issue 4).

Grove, S. J., Fisk, R.P.,, Pickett, G. M \& Kangun, N.(1996). Going Green in the Service Sector Social Responsibility Issues, Implications and Implementation. European Journal of Marketing, Vol.30, pp. 56-66.

Joshi, Y. \& Zillur Rahman (2015). Factors Affecting Green Purchase Behaviour and Future Research Directions.. International Strategic Management Review, Vol.3, pp. 128-143.

Khalid, I. \& Zainuddin. (2011). The Impact of Media Exposure on Intension to Purchase Green Electronic Products amongest Lecturers. International Journal of Business and Management, Vol.6(No.3).

Krause, D. (1993). Environmental Conciousness: An Empirical Study. Journal of Environment and Behavior, pp. 126-42.

Laroche, M., Jasmin Bergeron \& Guido Barbaro-Forleo. (2001). "Targeting consumers who are willing to pay more for environmentally friendly products". Journal of Consumer Marketing, Vol. 18(Issue:6), pp. 503-520.

Lowe, P. \& D. Morrison (1984). Bad news or good news: Environmental politics and mass media.. Sociological Review, Vol.32, pp. 75-90.

Lowe, P. \& W. Rudig (1987). Review article: Political ecology and the social science- The state of art.. British Journal of Political Science, Volume.16, pp. 513-550.

Mahesh, R. \& P. Gomathi (2016). A Study on Rural Consumers Buying Behaviour of Green Products with Reference to Selected Villages in Tiruppur District.. International Journal of Engineering and Management Research, volume-6(Issue-1), pp. 15-20. 
Maheswari, A. \& Malhotra. G. (2011). "Green Marketing: A Study on Indian Youth,. International Journal of Management and Strategy, Vol,1(No.II).

Mannarswamy, S. (2011). A Study of Environmental Awareness and the Changing Attitude of the Students and the Public in Coimbatore towards Green Products.. Research Journal of Social Science and Management, Vol.1, pp. 75-84.

Mazis \& Raymond. (1997). Consumer perceptions of health claims in advertisements and on food labels. The Journal of consumer affairs(USA), Vol:31(Issue:1).

McDougall, G. H. G. (1993). The Green Movement in Canada: Implications for Marketing Strategy.. Journal of International Consumer Marketing, Issue 5, pp. 69-87.

Mishra, P. \& Sharma, P. (2010). Green Marketing in India: Emerging Opportunities and Challenges.. Journal of Engineering, Science and Management Education, Vol.3, pp. 9-14.

Mitchell, R. (1990). "Public opinion and the green lobby: Poised for the 1990s?”, s.l.: s.n.

Murthy, P. (2010). Strategic Green Marketing for Survival, s.1.: s.n.

Oswan, A., Yusuf Hj, O., Shahrul, N. S. \& Muhammad, S. A. (2015). The Awareness and Implementation of Green Concepts in Markeitng Mix: A Case of Malaysia. Procedia Economics and Finance, pp. 428-433.

Ottman, J., 2008. The five simple rules of green marketing.. Design Management Review, Vol.19(4), pp. 65-69.

Ottman, J. A. (1992). Industrys Response to Green Consumerism.. Jounal of Business Strategy, Vol.13, pp. 3-7.

Petty, R. E. \& Cacioppo, J. T. (1990). Involvement and persuasion: Tradition versus integration., s.l.: Psychologoical Bulliten.

Polonsky, M. J. (1994). An Introduction to Green Marketing.. Electronic Green Jounal, Vol.1, pp. 1-9.

Prakash, A. (2002). Green marketing, public policy and managerial strategies.. Business Strategy and the environment, Vol. 11, pp. 285-297.

R., M. \& sakthivel. (2015). Customer's attitude and awareness towards green products with reference to Coimbatore- An analytical study.. International Journal of Multidisciplinary Research and Development, Vol. 2(1), pp. 152-158.

Rakshitha, T. (2011). Green Marketing. Indian Streams Research Journal, Vol.1, pp. 1-10.

Rambabu L and Sreeramulu D. (2019). Green products and consumer awareness level: A study. EPRA-International Journal of Multidisciplinary Research, Vol.5 (6), 88-93.

Rambabu L and Sreeramulu D (2019). Fmcg Green Marketing: A Study on Pre-Consumption Perspective of Customers. International Journal of Innovative Research in Management Studies, Vol. 4 (6); 1-11.

Roberts, J. A., 1996. Green consumers in the 1990s: profile and implications for advertising .. Journal of Business Research, Vol.36(3), pp. 217-231.

Schahn, J. \& Holzer, E. (1990). Studies of individual environmental concern: The role of knowledge, gender, and background variables.. Environment and Behaviour, Vol. 22(6), pp. 767-786.

Schlegemilch, B., Bohlen, G.M., \& Diamantopoulos,A. (1996). The Link between Green Purchasing Decisions and Measures of Environment Consciousness.. European Journal of Marketing, Vol.30, pp. 35-55. 
Schultz, P. \& Lauterborul, Z.C. (1993). Values and pro environmental behaviour: A five -country survey.. Journal of Cross-Cultral Psychology, Vol. 29(4), pp. 540-558.

Smith, A. (2009). The Wealth of Nation- A Landmark Classic by Adam Smith. Thriffy Books.

S, S. T. (2015). Awareness of Green Marketing and Its Influence on Buying Behaviour of Consumers in Kerala.. International Journal of Scientific Research and Management, Vol.5(Issue 07), pp. 6156-6164.

Tolliver-Nigro, H. (2009). “Green Market to Grow 267 Percent by 2015,”, s.1.: Matter Network.

Van Birgelen, M., Semeijn, J., \& Keicher, M. (2009). Packaging and proenvironmental Consumption Behaviour: Investigating Purchase and Disposal Decisions for Bevarages.. Environment and Behaviour, Vol. 41(1), pp. 125146.

Vig, N. \& M.E. Kraft(eds), n.d. In Environmental Policy in the 1990s: Towards a new agenda.. Congressional Quarterly, pp. 81-99.

Citation: Dr. Rambabu Lavuri, Prof. D. Sreeramulu , Green Marketing: Consumer Perception And Knowledge Level Towards Purchasing Eco Friendly Products, vol 6, no. 1, 2020, pp. 1-13.

Copyright (c) 2020 Dr. Rambabu Lavuri, et al. This is an open access article distributed under the Creative Commons Attribution License, which permits unrestricted use, distribution, and reproduction in any medium, provided the original work is properly cited. 